\section{Seasonal Production Smoothing}

\author{
Donald S. Allen
}

nventory investment dynamics appear to dominate the economy's historical movement around its long-run path. Blinder and Maccini (1991) show that the average movement in inventory investment during post-war recessions account for 87 percent of the peak-to-trough movement in Gross National Product (GNP). ${ }^{1}$ Because inventory fluctuations have historical ly played such a major role in business cycles (and possibly seasonal fluctuations), it is important to understand the theoretical motivation for inventory holdings and the implied dynamics. The received view, established by Holt, Modigliani, Muth and Simon (1960), is that inventories are used to smooth production in the presence of increasing marginal cost (convex costs). An empirical fact of inventory investment, however, is that production is more volatile than sales. The failure to confirm production smoothing empirically has been explained by inadequacies of the data or exceptions to the abstraction of convex costs.

Intuition suggests that even with convex costs, firms may not be likely to smooth production over periods longer than a year. Production horizons are likely to be shorter than a year and inventory holding costs may make it uneconomical to hold inventory for as long as a year. Many industries have well documented seasonal patterns in demand allowing them to plan production in concert with available capacity, required lead times, and labor market flexibility. In addition, evidence has been uncovered suggesting that seasonal fluctuations in output also can be affected by inventory/production decisions. For example, Carpenter and Levy (1998) use frequency domain analysis and find a large and statistically significant average squared coherence between inventory investment and the change in output in the manufacturing sector at both seasonal and business-cycle frequencies. It seems appropriate, therefore, to focus some attention on inventory decisions at seasonal frequencies.

In this paper we look for evidence of seasonal production smoothing in seasonally unadjusted monthly data on manufacturing and retail inventories and sales. Using detrended, seasonally unadjusted data we find that the variance of production is less than the variance of sales for 23 out of 35 industries. The equival ent test using seasonally adjusted data found none with production varying less than sales. We interpret this as stronger evidence of production smoothing than found in previous literature.

The Fourier series of the inventory-tosales (I/S) ratio of the industries with the lowest variance of production relative to sales revealed strong seasonal components (annual, six months, and three months). A strong seasonal component in the I/S ratio suggests a possible negative seasonal correlation between sales and inventory and is an intuitive indication that smoothing occurs at higher frequencies. ${ }^{2}$ The results confirm Ghali's (1987) finding of seasonal smoothing using detrended, seasonally unadjusted data for the cement industry. The results also suggest that a model other than production smoothing may be more appropriate for explaining trend movements in production relative to sales.

\section{Background and Literature Survey}

Holt, Modigliani, Muth, and Simon (1960) established the analytical framework demonstrating that optimizing firms facing convex production costs and uncertain demand are motivated to smooth production and
${ }^{1}$ There is some debate whether more recent practices still induce this effect. Allen (1995) suggests that recent improvements in inventory management may be reducing the "boom/ bust" effects of inventory swings, but empirical confirmation is not strong. Filardo (1995) finds no evidence of a muted inventory cycle.

2 If inventories are high when sales are low, and vice versa, then the I/ S ratio will fluctuate accordingly. Obviously, if inventory remained constant and sales varied seasonally, the I/ $S$ ratio also would fluctuate seasonally, so this is not an exact metric of smoothing. The seasonality of the ratio does suggest, however, the frequency over which smoothing is taking place. 
use inventories to buffer demand shocks. If the marginal cost of production is increasing, then storing output during periods of low demand is prudent as long as storage costs are sufficiently low. (See the shaded insert on page 5.) Much of the research in inventory since Holt et al., has focused on the efficacy of using the productionsmoothing paradigm at the macroeconomic level. If firms use inventories to smooth production, then production should vary less than sales. Empirical testing of this hypothesis has yielded mixed results. Using a simple test of the ratio of the variance of production to the variance of sales, a majority of researchers have found a ratio greater than 1.0, contradicting the theory.

As a rule, data on production are not available. Production can be readily estimated, however, by adding current period sales to the change in inventory from last period. If production exceeds (is less than) sales in a given period, then the difference must go to increasing (decreasing) inventories. This can be represented by the following equation:

$$
\mathrm{P}_{\mathrm{t}}=\mathrm{S}_{\mathrm{t}}+\Delta \mathrm{l}_{\mathrm{t}},
$$

where $P$ is production, $S$ is sales and $\Delta l$ is the change in inventory. This fundamental equation implies an important relationship among the variances and covariance of $P, S$, and $\Delta \mathrm{l}$ :

$$
\operatorname{Var}(\mathrm{P})=\operatorname{Var}(\mathrm{S})+\operatorname{Var}(\Delta \mathrm{l})+2 \operatorname{Cov}(\mathrm{S}, \Delta \mathrm{l})
$$

For the variance of production to be less than the variance of sales, the covariance of sales and the change in inventories, $\operatorname{Cov}(S, \Delta l)$ must be negative and greater in absolute value than half the variance of inventories.

Testing this covariance relationship, Miron and Zeldes (1988) find no support for production smoothing using both seasonally adjusted and unadjusted data after removing an estimated linear trend from monthly data. Blinder (1986) al so finds little empirical support for the basic production smoothing model. He identifies, however, conditions under which the facts could be compatible with production smoothing, to wit, if:
- Cost shocks are present,

- Firms see demand shocks before they make their production decisions,

- Demand shocks build before they decay,

- Or, technological parameters dictate a rapid speed of adjustment.

If firms do not face convex production costs, production smoothing is not optimal. Ramey (1991) finds indication of nonconvex costs in some industries. Blinder and M Mccini (1991) observe that wholesale and retail trade, and the materials and supplies portion of manufacturing inventory, make up a large portion of total inventories and are likely to face nontrivial "quasi-fixed" costs of ordering. This type of cost structure makes an $(S, S)$ inventory rule more economical. That is, firms will wait until inventory falls below a trigger point (s) then order sufficient stocks to raise inventory to an upper bound (S). This way the quasi-fixed costs are spread over a larger quantity. This behavior, sometimes called "bunching" will result in a higher volatility of production than sales. This leads Blinder and Maccini to conclude that the $(S, S)$ paradigm is more consistent with the empirical evidence.

Another source of empirical failure may be the data. Ghali (1987) demonstrated that seasonal adjustment and aggregation will remove evidence of seasonal smoothing, and Lai (1991) shows that aggregation can distort the data sufficiently to negate production-smoothing tests. Some researchers, using disaggregated physical product data, find some support for production smoothing. Fair (1989), and Krane and Braun (1991) use disaggregated physical product data for the United States and confirm smoothing in several industries, while Beason (1993) has similar success with Japanese data. Dimelis and Ghali (1994) detect statistically significant evidence of smoothing in disaggregated physical product data for three out of five industries, using the variance 
bounds test introduced by West (1986) and generalized by Kollintzas (1995).

Physical unit information is more appropriate for testing the implications of inventory management. It makes more sense, when discussing the motivation for holding inventory, to talk about the number of cars in stock than the value. Unfortunately, the most readily accessible data, particularly at an aggregate level, are the nominal values of inventory. One way of getting closer to physical quantities is to remove the effects of price changes. Finding the appropriate price deflator to convert the nominal values to real values is a difficult task. And, even when data are converted to remove price increases, trend growth in the real level of sales al so can disguise smoothing. If sales are trending up (down), then production will also trend up (down). If firms smooth production annually and adjust the target level of smoothed production each year, then the variance induced by the trend growth also will distort the smoothing measure.

Miron (1996) page 18 finds noticeably less seasonal variation in price variables than quantity variables.

Seasonal movements in both real and nominal price variables are noticeably smaller than those in quantity variables. For example, the standard deviation of the seasonals in the growth rates of prices is 0.2 percent, and seasonal dummies explain only 3.1 percent of the total variation. The same conclusions hold qualitatively for nominal interest rates, real interest rates, nominal wages, and real wages. Miron (1996).

This observation means that if we remove the trend from seasonally unadjusted data, the high frequency movements are more likely to reflect changes in quantities. This provides justification for the data transformation that we discuss in the next section.

\section{DATA SOURCE AND TRANS- FORMATION}

The data used are from the Census Bureau's monthly data on manufacturing

\section{Table 1}

Industries Analyzed

All Manufacturing Industries

Stone, Clay and Glass (SIC 32)

Primary Metals (SIC 33)

Nonferrous and other Primary Metals

Fabricated Metal Products (SIC 34)

Industrial Machinery and Equipment (SIC 35)

Electrical Machinery (SIC 36)

Transportation Equipment (SIC 37)

Instruments/ Related Products (SIC 38)

All Other Durable Goods

Nondurable Goods Manufacturing Industries

Tobacco Products (SIC 21)

Textile Mill Products (SIC 22)

Paper and Allied Products (SIC 26)

Chemical and Allied Products (SIC 28)

Petroleum and Coal Products (SIC 29)

Automotive Equipment

Home Goods and Apparel

Consumer Staples

Machinery and Equipment*

Business Supplies

Construction Materials/Supplies / Intermediate

Capital Goods Industries

Producers' Durable Equipment*

Household Durable Goods

All Retail

Retail: Durable Goods Stores

Retail: Bldg Matls/ Hdwre/ Garden Supply/

Mobile Home Dealers (SIC 52)

Retail: Automotive Dealers (SIC 55)

Retail: Furniture, Home Furnishings \&

Eqpt Stores (SIC 57)

Retail: Nondurable Goods Stores

Retail: General Merchandise Group Stores (SIC 53)

Retail: Department Stores ex Leased

Departments (SIC 531)

Retail: Food Stores (SIC 54)

Retail: Apparel and Accessory Stores (SIC 56)

* Data available starting in 1968.
Years of Data

$1 / 58$ to $12 / 98$

$1 / 58$ to $12 / 98$

$1 / 58$ to $12 / 98$

$1 / 58$ to $12 / 98$

$1 / 58$ to $12 / 98$

$1 / 58$ to $12 / 98$

$1 / 58$ to $12 / 98$

$1 / 58$ to $12 / 98$

$1 / 58$ to $12 / 98$

$1 / 58$ to $12 / 98$

$1 / 58$ to 12/ 98

$1 / 58$ to $12 / 98$

$1 / 58$ to $12 / 98$

$1 / 58$ to $12 / 98$

$1 / 58$ to 12/ 98

$1 / 58$ to $12 / 98$

$1 / 58$ to $12 / 98$

$1 / 58$ to $12 / 98$

$1 / 58$ to $12 / 98$

$1 / 68$ to 12/98

$1 / 58$ to $12 / 98$

$1 / 58$ to $12 / 98$

$1 / 58$ to $12 / 98$

$1 / 68$ to 12/98

$1 / 58$ to $12 / 98$

$1 / 87$ to $12 / 98$

$1 / 87$ to $12 / 98$

$1 / 87$ to $12 / 98$

$1 / 87$ to $12 / 98$

$1 / 87$ to $12 / 98$

$1 / 87$ to $12 / 98$

$1 / 87$ to $12 / 98$

$1 / 87$ to $12 / 98$

$1 / 87$ to $12 / 98$

$1 / 87$ to $12 / 98$ 


\section{Figure 1}

Stone, Clay and Glass Products

(Monthly Sales, Seasonally Unadjusted, Millions of Current Dollars)
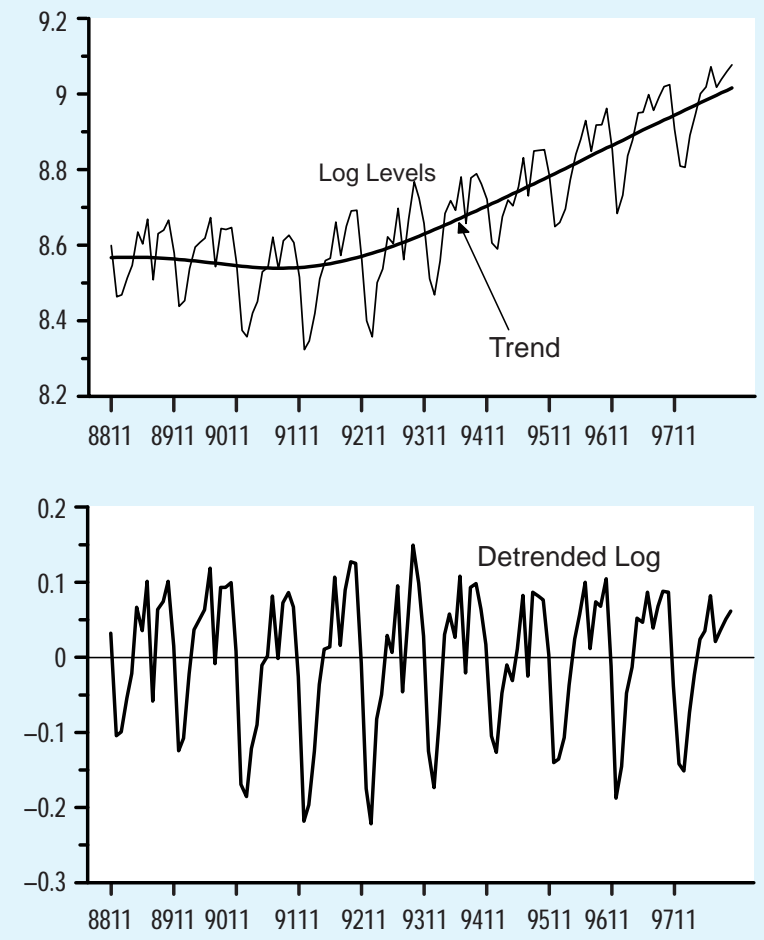

${ }^{3}$ Harvey (1994), chapter 6, provides an excellent exposition of frequency domain analysis. for the most recent 10 years for the Stone, Clay and Glass manufacturing industry. The smooth line shows the trend that is extracted to get the filtered data.

\section{Frequency Domain}

Looking at the data in the frequency domain highlights the effect of the seasonal adjustment and the HP filter. ${ }^{3}$ The Fourier series representation decomposes the data into the contribution of individual frequencies to the variance. The vertical axis indicates the value of the coefficient applied to that frequency. If there is a trend present, there will be a large contribution from the low frequencies. If there is a strong contribution at a particular frequency compared to others, there will be a noticeable spike at that frequency. The Fourier series displayed here are truncated at 1.0 to focus attention on the higher frequency components.

Figure 2 compares the Fourier series of the logarithm of sales for Stone, Clay and Glass Industries for the raw seasonally unadjusted series, the seasonally adjusted series, and the series after an HP filtered trend is removed from the raw (unadjusted) data. The spikes in the unadjusted data occur at cycles of 12 months, six months, four months and 3 months, reflecting harmonics of the seasonal cycle. The appearance of harmonics in the data may reflect the aggregation of individual firms with seasonal cycles that are offset, (i.e. some may have peak sales in winter while others peak during the summer). The seasonally adjusted data have no spikes. The HP filtered data show the absence of the low frequency components (zero near the origin), while the high frequency contributions appear to be intact. Figure 3 shows the I/S ratio of selected industries, and Figure 4 shows the Fourier series of the ratios. In the next section, we report the results of the variance ratio test, then compare this to the frequency spectra of the I/S ratios of the sectors.

\section{Results}

The typical measure of production smoothing is the ratio of the variance of 


\section{REVIEW}

\section{THE PRODUCTION SMOOTHING WITH TREND}

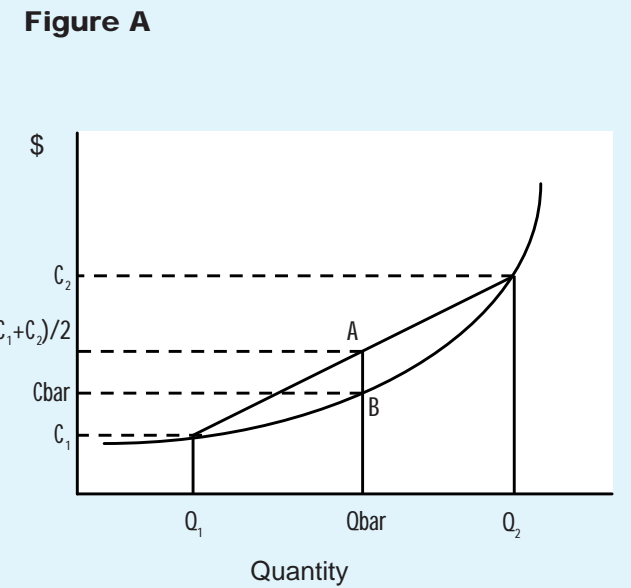

Figure A

Figure B

Periodic Production Smoothing

Figure $\mathrm{A}$ illustrates the production smoothing motivation when increasing marginal costs exist. If $Q_{1}$ and $Q_{2}$ represent the demand in periods 1 and 2 respectively, then the point $A$ represents the average cost, $\left(C_{1}+C_{2}\right) / 2$, if $Q_{1}$ is produced during period 1 and $Q_{2}$ is produced during period 2. Point $B$ represents the average cost, $C$ bar, if $\left(Q_{1}+Q_{2}\right) / 2$ is produced during both periods, with the excess produced in period 1 carried over to period 2 . The trade off is between the cost of storage for one period versus the saving from smoothing. The difference between $A$ and $B$ must be greater than the cost of holding inventory to justify smoothing. Note also that if mean demand is expected to decrease below current production for an extended period (i.e., $Q_{2}$ is current demand and $Q_{1}$ is next period's expected demand), then it becomes optimal to reduce production and serve part of the current demand from inventory. Thus production-smoothing motivation can lead to level changes if forecast sales change direction.

Figure B illustrates how periodic adjustments to production to match trend growth can result in lumpy movements in production even with production smoothing. The blue line indicates trend growth in sales with a seasonal component. If sales are forecast and production planned at the beginning of each period, then P1 represents the production level for the first period, P2 the second period, and P3 the third period. During the first half of each period, production exceeds sales and the difference goes into inventory. During the second half of the period, production is less than sales and the difference is made up out of inventory. Each period, production is smoothed. Because of the trend growth in sales, however, production jumps at the start of each new period. If data over all three periods are used, the variance of production may exceed the variance of sales.

production to the variance of sales. ${ }^{4} \mathrm{~A}$ ratio more than 1.0 implies that production is more volatile than sales and, therefore, contradicts the smoothing hypothesis. A negative correlation between sales and the change in inventory may be insufficient to produce a lower variance in production than in sales. Tables 2, 3, and 4 summarize
${ }^{4}$ A more appropriate test of production smoothing would be a comparison of the variance of production to the variance of forecasted sales. 


\section{Manufacturing}

\begin{tabular}{|c|c|c|c|c|c|c|}
\hline & & Variance & Variance & Covariance & Variance & Variance Ratio \\
\hline & & Sales & $\begin{array}{l}\text { Inventory } \\
\text { Investment }\end{array}$ & $\begin{array}{c}\text { Sales and } \\
\text { Inven. Invest. }\end{array}$ & Production & \\
\hline \multirow[t]{2}{*}{ All Manufacturing Industries } & NSA & 0.00272 & 0.00029 & -0.00015 & 0.00270 & 0.99554 \\
\hline & SA & 0.00061 & 0.00014 & 0.00009 & 0.00092 & 1.50964 \\
\hline \multirow[t]{2}{*}{ Stone, Clay and Glass (SIC 32) } & NSA & 0.00883 & 0.00076 & -0.00176 & 0.00606 & 0.68635 \\
\hline & SA & 0.00117 & 0.00023 & 0.00000 & 0.00141 & 1.20013 \\
\hline \multirow[t]{2}{*}{ Primary Metals (SIC 33) } & NSA & 0.01106 & 0.00072 & -0.00015 & 0.01148 & 1.03841 \\
\hline & SA & 0.00731 & 0.00054 & 0.00035 & 0.00855 & 1.16922 \\
\hline \multirow[t]{2}{*}{ Nonferrous and other Primary Metals } & NSA & 0.00729 & 0.00059 & 0.00010 & 0.00808 & 1.10774 \\
\hline & SA & 0.00462 & 0.00037 & 0.00021 & 0.00541 & 1.17196 \\
\hline \multirow{2}{*}{$\begin{array}{l}\text { Fabricated Metal Products } \\
\text { (SIC 34) }\end{array}$} & NSA & 0.00399 & 0.00112 & -0.00027 & 0.00456 & 1.14233 \\
\hline & SA & 0.00104 & 0.00065 & 0.00011 & 0.00190 & 1.83141 \\
\hline \multirow[t]{2}{*}{ Industrial Machinery and Equipment (SIC 35) } & NSA & 0.00721 & 0.00123 & -0.00089 & 0.00667 & 0.92451 \\
\hline & SA & 0.00133 & 0.00050 & 0.00029 & 0.00240 & 1.80271 \\
\hline \multirow[t]{2}{*}{ Electrical Machinery (SIC 36) } & NSA & 0.00496 & 0.00086 & -0.00020 & 0.00542 & 1.09311 \\
\hline & SA & 0.00104 & 0.00034 & 0.00022 & 0.00182 & 1.75383 \\
\hline \multirow{2}{*}{$\begin{array}{l}\text { Transportation Equipment } \\
\text { (SIC 37) }\end{array}$} & NSA & 0.01422 & 0.00118 & -0.00148 & 0.01244 & 0.87488 \\
\hline & SA & 0.00388 & 0.00039 & -0.00014 & 0.00399 & 1.02722 \\
\hline \multirow{2}{*}{$\begin{array}{l}\text { Instruments/ Related Products } \\
\text { (SIC 38) }\end{array}$} & NSA & 0.00418 & 0.00121 & -0.00074 & 0.00391 & 0.93591 \\
\hline & SA & 0.00072 & 0.00058 & 0.00003 & 0.00137 & 1.89900 \\
\hline \multirow[t]{2}{*}{ All Other Durable Goods } & NSA & 0.00634 & 0.00048 & -0.00046 & 0.00590 & 0.92985 \\
\hline & SA & 0.00155 & 0.00024 & 0.00012 & 0.00204 & 1.31248 \\
\hline \multirow{2}{*}{$\begin{array}{l}\text { Nondurable Goods } \\
\text { Manufacturing Industries }\end{array}$} & NSA & 0.00164 & 0.00019 & -0.00006 & 0.00171 & 1.03902 \\
\hline & SA & 0.00038 & 0.00011 & 0.00005 & 0.00058 & 1.52003 \\
\hline \multirow[t]{2}{*}{ Tobacco Products (SIC21) } & NSA & 0.01631 & 0.02009 & -0.00220 & 0.03199 & 1.96182 \\
\hline & SA & 0.00396 & 0.00469 & -0.00005 & 0.00855 & 2.15891 \\
\hline \multirow[t]{2}{*}{ Textile Mill Products (SIC 22) } & NSA & 0.00668 & 0.00099 & -0.00073 & 0.00620 & 0.92822 \\
\hline & SA & 0.00139 & 0.00025 & 0.00012 & 0.00188 & 1.35705 \\
\hline \multirow{2}{*}{$\begin{array}{l}\text { Paper and Allied Products } \\
\text { (SIC 26) }\end{array}$} & NSA & 0.00227 & 0.00023 & 0.00008 & 0.00265 & 1.16834 \\
\hline & SA & 0.00109 & 0.00011 & 0.00014 & 0.00148 & 1.35517 \\
\hline \multirow{2}{*}{$\begin{array}{l}\text { Chemical and Allied Products } \\
\text { (SIC 28) }\end{array}$} & NSA & 0.00338 & 0.00038 & -0.00036 & 0.00304 & 0.89854 \\
\hline & SA & 0.00096 & 0.00019 & 0.00010 & 0.00134 & 1.40595 \\
\hline \multirow{2}{*}{$\begin{array}{l}\text { Petroleum and Coal Products } \\
\text { (SIC 29) }\end{array}$} & NSA & 0.00534 & 0.00080 & 0.00032 & 0.00678 & 1.27019 \\
\hline & SA & 0.00423 & 0.00058 & 0.00036 & 0.00552 & 1.30557 \\
\hline
\end{tabular}




\section{Table 3}

\section{"Other" Manufacturing}

\begin{tabular}{|c|c|c|c|c|c|c|}
\hline & & Variance & Variance & Covariance & Variance & Variance Ratio \\
\hline & & Sales & $\begin{array}{l}\text { Inventory } \\
\text { Investment }\end{array}$ & $\begin{array}{l}\text { Sales and } \\
\text { Inven. Invest. }\end{array}$ & Production & \\
\hline Automotive Equipment & $\begin{array}{l}\text { NSA } \\
\text { SA }\end{array}$ & $\begin{array}{l}0.02848 \\
0.00898\end{array}$ & $\begin{array}{l}0.00097 \\
0.00027\end{array}$ & $\begin{array}{l}-0.00213 \\
-0.00012\end{array}$ & $\begin{array}{l}0.02518 \\
0.00901\end{array}$ & $\begin{array}{l}0.88435 \\
1.00339\end{array}$ \\
\hline Home Goods and Apparel & $\begin{array}{l}\text { NSA } \\
\text { SA }\end{array}$ & $\begin{array}{l}0.00898 \\
0.00088\end{array}$ & $\begin{array}{l}0.00138 \\
0.00024\end{array}$ & $\begin{array}{r}-0.00195 \\
0.00014\end{array}$ & $\begin{array}{l}0.00647 \\
0.00140\end{array}$ & $\begin{array}{l}0.72049 \\
1.58834\end{array}$ \\
\hline Consumer Staples & $\begin{array}{l}\text { NSA } \\
\text { SA }\end{array}$ & $\begin{array}{l}0.00133 \\
0.00032\end{array}$ & $\begin{array}{l}0.00035 \\
0.00014\end{array}$ & $\begin{array}{l}0.00004 \\
0.00002\end{array}$ & $\begin{array}{l}0.00177 \\
0.00049\end{array}$ & $\begin{array}{l}1.32663 \\
1.52705\end{array}$ \\
\hline Machinery and Equipment & $\begin{array}{l}\text { NSA } \\
\text { SA }\end{array}$ & $\begin{array}{l}0.00722 \\
0.00096\end{array}$ & $\begin{array}{l}0.00130 \\
0.00041\end{array}$ & $\begin{array}{r}-0.00142 \\
0.00012\end{array}$ & $\begin{array}{l}0.00567 \\
0.00161\end{array}$ & $\begin{array}{l}0.78549 \\
1.68163\end{array}$ \\
\hline Business Supplies & $\begin{array}{l}\text { NSA } \\
\text { SA }\end{array}$ & $\begin{array}{l}0.00183 \\
0.00051\end{array}$ & $\begin{array}{l}0.00033 \\
0.00019\end{array}$ & $\begin{array}{r}-0.00015 \\
0.00004\end{array}$ & $\begin{array}{l}0.00186 \\
0.00078\end{array}$ & $\begin{array}{l}1.01557 \\
1.54868\end{array}$ \\
\hline Construction Materials/ Supplies / Intermediate & $\begin{array}{l}\text { NSA } \\
\text { SA }\end{array}$ & $\begin{array}{l}0.00563 \\
0.00124\end{array}$ & $\begin{array}{l}0.00041 \\
0.00020\end{array}$ & $\begin{array}{r}-0.00052 \\
0.00012\end{array}$ & $\begin{array}{l}0.00499 \\
0.00167\end{array}$ & $\begin{array}{l}0.88617 \\
1.35123\end{array}$ \\
\hline Capital Goods Industries & $\begin{array}{l}\text { NSA } \\
\text { SA }\end{array}$ & $\begin{array}{l}0.00694 \\
0.00080\end{array}$ & $\begin{array}{l}0.00144 \\
0.00048\end{array}$ & $\begin{array}{r}-0.00163 \\
0.00010\end{array}$ & $\begin{array}{l}0.00513 \\
0.00148\end{array}$ & $\begin{array}{l}0.73934 \\
1.85593\end{array}$ \\
\hline Producers' Durable Equipment & $\begin{array}{l}\text { NSA } \\
\text { SA }\end{array}$ & $\begin{array}{l}0.00667 \\
0.00120\end{array}$ & $\begin{array}{l}0.00083 \\
0.00033\end{array}$ & $\begin{array}{r}-0.00066 \\
0.00010\end{array}$ & $\begin{array}{l}0.00619 \\
0.00173\end{array}$ & $\begin{array}{l}0.92711 \\
1.43817\end{array}$ \\
\hline Household Durable Goods & $\begin{array}{l}\text { NSA } \\
\text { SA }\end{array}$ & $\begin{array}{l}0.00840 \\
0.00114\end{array}$ & $\begin{array}{l}0.00149 \\
0.00047\end{array}$ & $\begin{array}{r}-0.00133 \\
0.00018\end{array}$ & $\begin{array}{l}0.00723 \\
0.00196\end{array}$ & $\begin{array}{l}0.86042 \\
1.72187\end{array}$ \\
\hline
\end{tabular}

the results, showing the variance of sales, inventories and the covariance of sales and the change in inventories. Of the 35 seasonally unadjusted series, there are only three manufacturing industries with positive covariances between sales and the change in inventories: Nonferrous and Other Primary M etals (a sub-category of Primary M etals); Paper and Allied Products; and, the Petroleum and Coal Products. By contrast, the covariances of all but three manufacturing series with seasonally adjusted data are positive. The seasonally adjusted retail data indicate some with negative covariance of inventory investment and sales, but none sufficiently negative to result in a variance ratio less than 1.0.

\section{Manufacturing}

The variance ratio of the detrended seasonally unadjusted data for all manufacturing is less than 1.0, but only barely; leaving unanswered the question of whether the production-smoothing model is adequate at this level of aggregation. At the twodigit SIC level of aggregation, SIC codes 33,34 , and 36 have variance ratios greater than 1.0 for the detrended log data, while SIC codes 32, 35, 37, and 38, as well as the "all other durable goods" category have variance ratios less than 1.0. The implication is that most durable goods industries smooth production over high frequency periods. $^{5}$ The seasonally adjusted data do not show smoothing, indicating that
${ }^{5}$ This implication holds at least if we interpret production smoothing as meaning that the growth rate of production varies less than the growth rate of sales. 


\section{Retail}

\begin{tabular}{|c|c|c|c|c|c|c|}
\hline & & Variance & Variance & Covariance & Variance & Variance Ratio \\
\hline & & Sales & $\begin{array}{l}\text { Inventory } \\
\text { Investment }\end{array}$ & $\begin{array}{l}\text { Sales and } \\
\text { Inven. Invest. }\end{array}$ & Production & \\
\hline \multirow[t]{2}{*}{ All Retail } & NSA & 0.00630 & 0.00222 & -0.00206 & 0.00439 & 0.69691 \\
\hline & SA & 0.00011 & 0.00009 & -0.00001 & 0.00018 & 1.68785 \\
\hline \multirow[t]{2}{*}{ Retail: Durable Goods Stores } & NSA & 0.00618 & 0.00264 & -0.00116 & 0.00650 & 1.05145 \\
\hline & SA & 0.00046 & 0.00038 & -0.00004 & 0.00077 & 1.67262 \\
\hline \multirow{2}{*}{$\begin{array}{l}\text { Retail: Bldg Matls/ Hdwre/ Garden Supply/ } \\
\text { Mobile Home Dealers (SIC 52) }\end{array}$} & NSA & 0.02100 & 0.00199 & -0.00361 & 0.01576 & 0.75081 \\
\hline & SA & 0.00065 & 0.00034 & 0.00003 & 0.00104 & 1.60598 \\
\hline \multirow[t]{2}{*}{ Retail: Automotive Dealers (SIC 55) } & NSA & 0.00805 & 0.00402 & -0.00241 & 0.00727 & 0.90217 \\
\hline & SA & 0.00075 & 0.00087 & -0.00016 & 0.00130 & 1.72889 \\
\hline \multirow{2}{*}{$\begin{array}{l}\text { Retail: Furniture, Home Furnishings } \\
\text { \& Eqpt Stores (SIC 57) }\end{array}$} & NSA & 0.01237 & 0.00749 & -0.00483 & 0.01021 & 0.82485 \\
\hline & SA & 0.00041 & 0.00058 & 0.00004 & 0.00107 & 2.63839 \\
\hline \multirow[t]{2}{*}{ Retail: Nondurable Goods Stores } & NSA & 0.00809 & 0.00270 & -0.00325 & 0.00430 & 0.53181 \\
\hline & SA & 0.00006 & 0.00004 & 0.00000 & 0.00009 & 1.45016 \\
\hline \multirow{2}{*}{$\begin{array}{l}\text { Retail: General Merchandise } \\
\text { Group Stores (SIC 53) }\end{array}$} & NSA & 0.04588 & 0.01966 & -0.02139 & 0.02276 & 0.49608 \\
\hline & SA & 0.00011 & 0.00037 & -0.00004 & 0.00041 & 3.60050 \\
\hline \multirow{2}{*}{$\begin{array}{l}\text { Retail: Department Stores } \\
\text { ex Leased Departments (SIC 31) }\end{array}$} & NSA & 0.04906 & 0.02083 & -0.02225 & 0.02539 & 0.51750 \\
\hline & SA & 0.00013 & 0.00043 & -0.00005 & 0.00046 & 3.70666 \\
\hline \multirow[t]{2}{*}{ Retail: Food Stores (SIC 54) } & NSA & 0.00190 & 0.00019 & -0.00006 & 0.00198 & 1.04026 \\
\hline & SA & 0.00008 & 0.00002 & 0.00000 & 0.00010 & 1.28350 \\
\hline \multirow[t]{2}{*}{ Retail: Apparel and Accessory Stores (SIC 56) } & NSA & 0.03814 & 0.01931 & -0.01861 & 0.02023 & 0.53035 \\
\hline & SA & 0.00030 & 0.00048 & 0.00002 & 0.00082 & 2.73757 \\
\hline
\end{tabular}

removing the higher frequencies from the data masks evidence of smoothing.

In the nondurable goods category in Table 2, only Textile Mill Products (SIC 22) and Chemical and Allied Products (SIC 28) have variance ratios less than 1.0 for the detrended log seasonally unadjusted data. The aggregate nondurable goods industries has a variance ratio greater than 1.0. Intuitively, we would expect production of some nondurables to be less amenable to storage. For instance, Tobacco Products may be largely influenced by crop size rather than by demand, while demand may be less elastic seasonally. Of the nine other manufacturing sectors, which reflect a lower level of aggregation, evidence of smoothing is revealed in seven when seasonally unadjusted data are used. (See Table 3). This suggests that aggregation may be playing a role as well.

\section{Retail Sector}

The seasonally unadjusted data for the retail sector reveal smoothing by most industries, suggesting that some retail 


\section{REVIEW}

SEPTEMBER/ O CTOBER 1999

firms may accumulate inventory in anticipation of seasonal increases in sales. Retail Food Stores (SIC 54) and aggregate of Retail Durable Goods stores are the only two of the 10 series that have a variance ratio higher than 1.0. Given that fixed costs associated with transportation are likely to induce $(S, S)$ behavior at the retail level, detecting smoothing may appear to be contradictory. Here again, however, the frequency of observation influences the detection of the underlying decision rule. It is likely that adjustments to inventory based on the $(S, S)$ rule takes place at frequencies less than one month. So, on average, inventory moves between upper and lower bounds within a month. Consequently, monthly data reveals seasonal movements in the bandwidth, while obscuring higher fre quency $(S, S)$ movements. Seasonal smoothing at the retail level does not preclude $(S, S)$ behavior at higher frequency. In addition, aggregation over a large number of establishments is likely to dampen high frequency movements.

\section{CONCLUSIONS}

Empirical evidence of production smoothing has been relatively elusive. Part of the problem appears to be the tendency to use seasonally adjusted data. This paper finds that smoothing takes place in a large proportion of manufacturing industries at seasonal frequencies or higher. Seasonal adjustment of the data removes this evidence. Removing the trend from the data allows us to exclude changes in production associated with trend growth in sales. This confirms empirical results of Allen (1997B), which suggest that inventory management at the firm level reflects planned and unplanned changes. The trend component of production reflects planned additions to inventory levels based on trend movement in sales, while the higher frequency component of production reflects smoothing over shorter horizons. Evidence of seasonal smoothing in the retail sectors suggests that retail firms al so manage inventory to smooth seasonal fluctuations in sales. Although smoothing is not generally associated with retail inventory management, it is not inconsistent with $(\mathrm{S}, \mathrm{S})$ behavior at frequencies higher than the observed data.

In summary, we find evidence of production smoothing at relatively high frequencies when the trend is removed from seasonally unadjusted data. We interpret this to

\section{Figure 2}

Fourier Spectrum of Stone, Clay

and Glass Industries Sales

(Seasonally Adjusted and Unadjusted)

Seasonally Adjusted

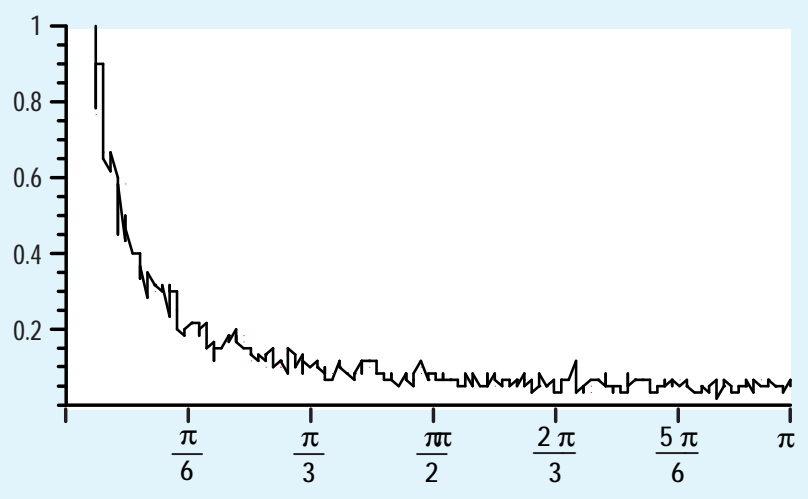

Seasonally Unadjusted

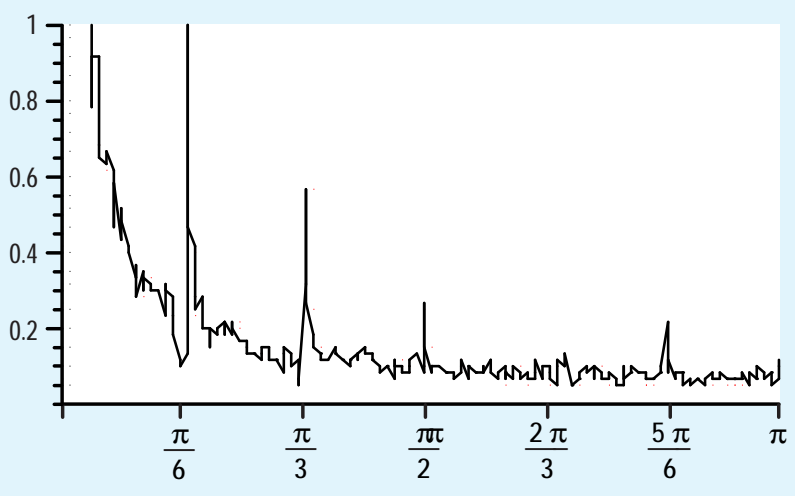

HP Filtered

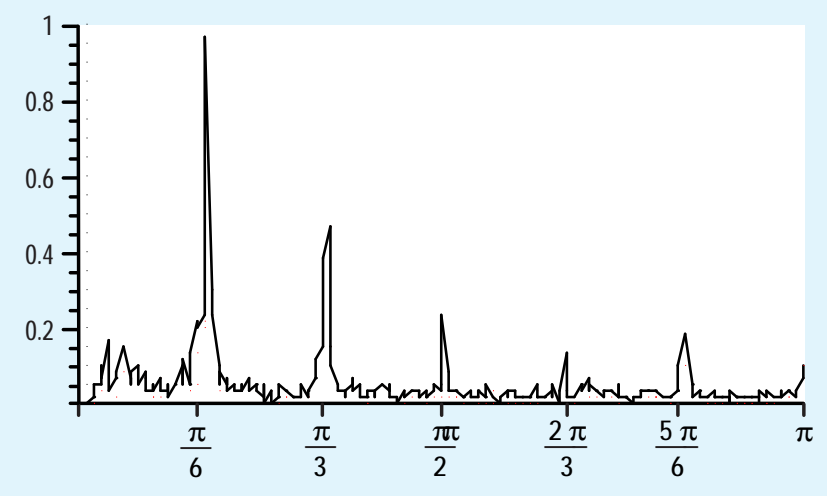

mean that using data that has been seasonally adjusted and includes trend growth, limits the ability to extract the 


\section{Inventory-to-Sales Ratios Selected Industries}

Home Goods and Apparel

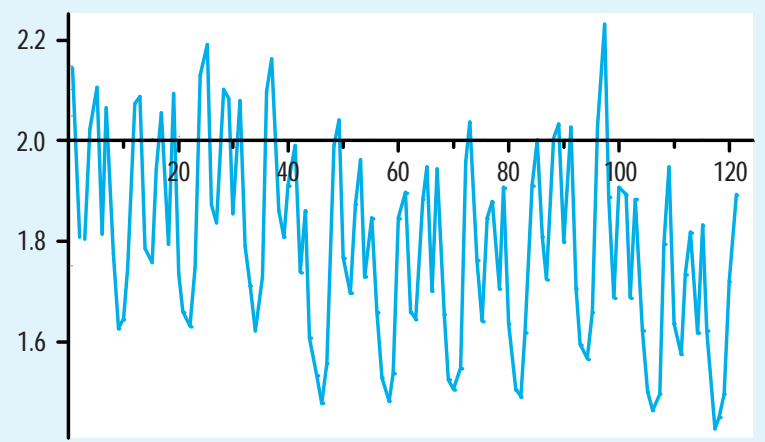

Capital Goods Industries

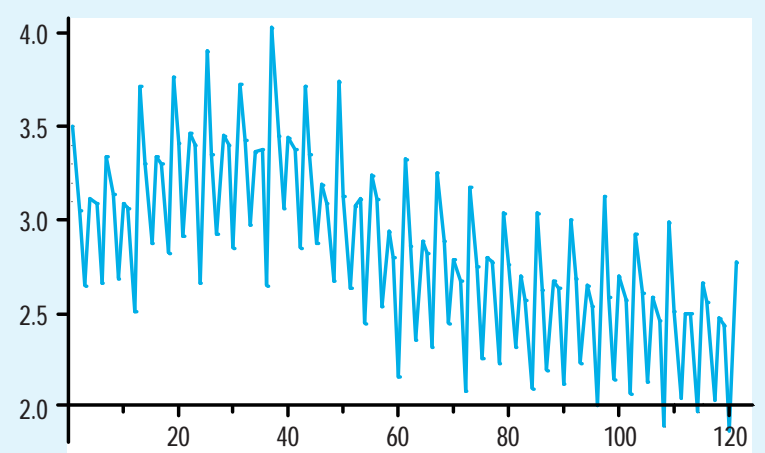

Machinery and Equipment

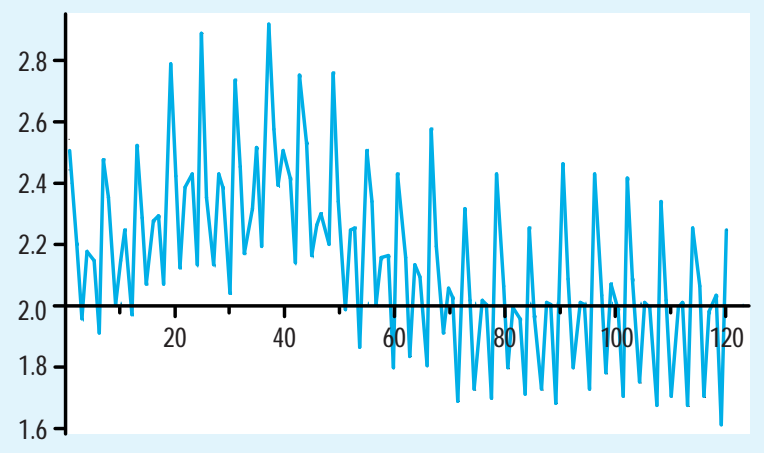

Stone, Clay and Glass Products

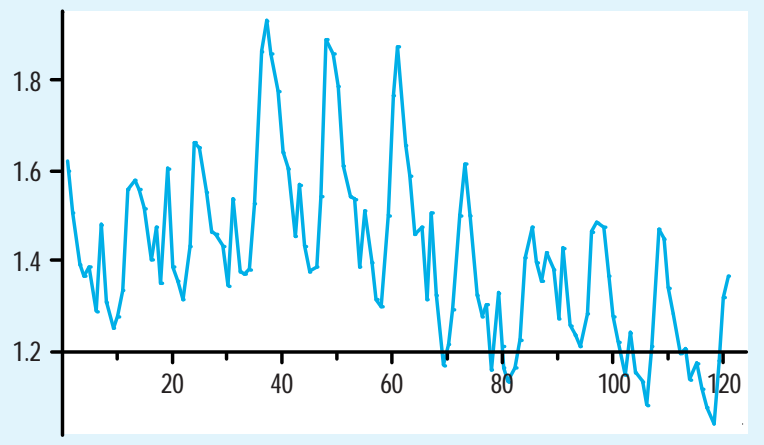

underlying motivation for holding inventories. To the extent that seasonal cycles mimic business cycles, analysis of production/inventory behavior at seasonal frequencies may provide insights into business cycle dynamics.

\section{REFERENCES}

Allen, Donald S. "A Multi-Sector Inventory Model," Journal of Economic Behavior and Organization, (January 1997A), pp. 55-87.

. "Do Inventories Moderate Fluctuations in Output?" this Review, (July/ August 1997B), pp. 39-50.

. "Changes in Inventory Management and the Business Cycle," this Review, (J uly/ August 1995), pp. 17-26.

Beason, Richard. "Tests of Production Smoothing in Selected Japanese Industries," Journal of Monetary Economics, (June 1993), pp. 381-94.
Blinder, Alan S. "Retail Inventory Behavior and Business Fluctuations," Brookings Papers on Economic Activity, 2 (1981), pp. 443-505.

. "Can the Production Smoothing Model of Inventory Behavior be Saved?" Quarterly Journal of Economics, (August, 1986), pp. $431-53$.

., and Louis J. Maccini. "The Resurgence of Inventory Research: What Have We Leamed? " Journal of Economic Surveys (1991), pp. 291-328.

Carpenter, Robert $E_{1}$, and Daniel Lewy. "Seasonal Cycles, Business Cycles, and the Comovement of Inventory Investment and Output," Joumal of Money, Credit, and Banking, (August 1998), pp. 331-46.

Dimelis, Sophia P., and Moheb A. Ghali. "Classical and Variance Bounds Tests of the Production Smoothing Hypothesis," International J oumal of Production Economics, (June 1994), pp. 15-22.

Fair, Ray C. "The Production-Smoothing Model is Alive and Well," Joumal of Monetary Economics, (November 1989), pp. 353-70. 


\section{REVIEW}

SEPTEMBER/ O CTOBER 1999

\section{Figure 4}

Fourier Spectrum of Inventory-to-Sales Ratios, Selected Industries

Home Goods and Apparel Machinery and Equipmentl
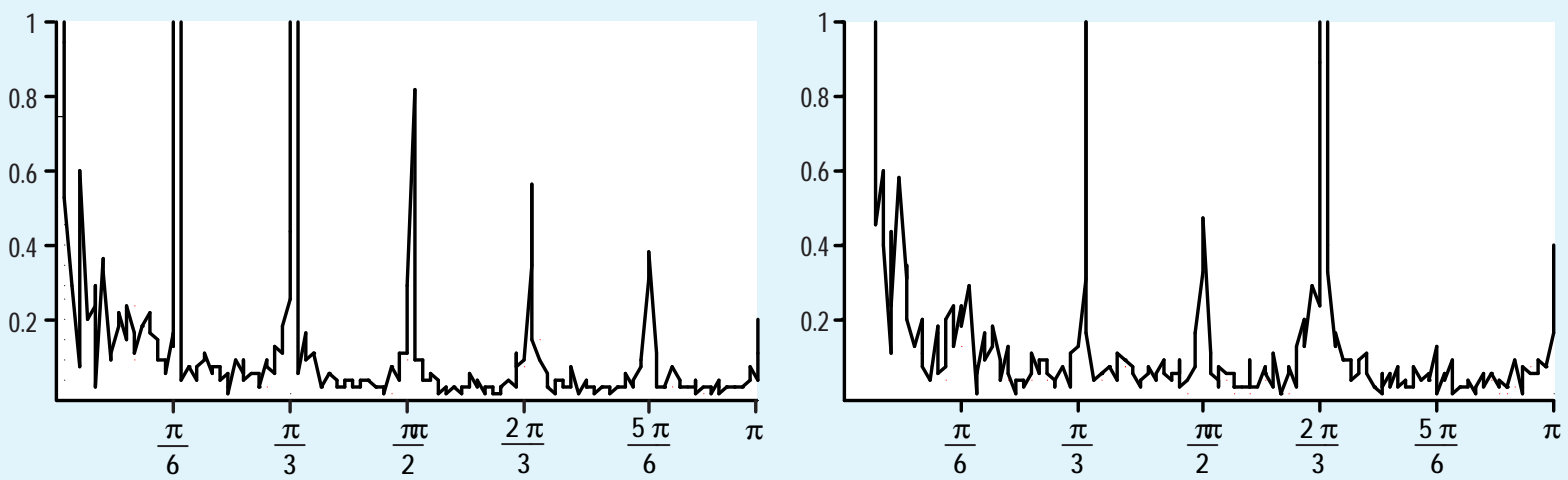

Capital Goods Industries

Stone, Clay and Glass Products
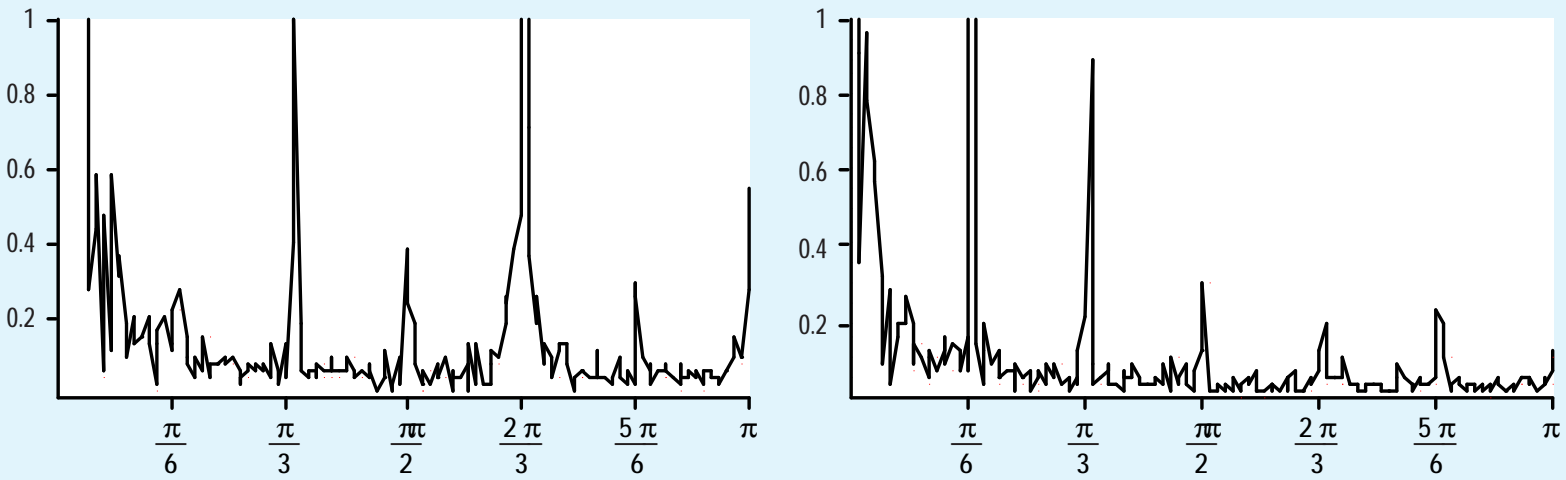

Filardo, Andrew ]. "Recent Evidence on the Muted Inventory Cycle," Federal Reserve Bank of Kansas City Economic Review, (second quarter 1995), pp. 27-43.

Ghali, Moheb A. "Seasonality, Aggregation and the Testing of the Production Smoothing Hypothesis," The American Economic Review (June 1987), pp. 464-69.

Harvey, Andrew C. Time Series Models, Second Edition, (1994), The MIT Press, Cambridge, Massachusetts.

Holt, Charles C., Franco Modigliani, John F. Muth, and Herbert A. Simon. Planning Production, Inventories, and Work Force (1960), PrenticeHall Inc., Englewood Cliffs, NJ.

Kollintzas, Tryphon. "A Generalized Variance Bounds Test with an Application to the Holt et al. Inventory Model," Journal of Economic Dynamics and Control, (Jan/ Feb 1995), pp. 59-89.
Krane, Spencer D., and Stephen N. Braun. "Production Smoothing Evidence from Physical-Product Data," Joumal of Political Economy, (June 1991), pp. 558-81.

Lai, Kon S. "Aggregation and Testing of the Production Smoothing Hypothesis," Intemational Economic Review, (May 1991), pp. 391403.

Miron, Jeffrey A., and Stephen P. Zeldes. "Seasonality, Cost Shocks, and the Production Smoothing Model of Inventories," Econometrica, (July 1988), pp. 877-908.

Miron, Jeffrey A. The Economics of Seasonal Cycles, (1996), Massachusetts Institute of Technology, Cambridge, Massachussets.

Ramey, Valerie A. "Nonconvex Costs and the Behavior of Inventories," Journal of Political Economy, (April 1991), pp. 306-34.

West, Kenneth D. "A Variance Bounds Test of the Linear Quadratic Inventory Model," Journal of Political Economy, (April 1986), pp. 374-401. 


\section{FOURIER SERIES}

Figures $1 \mathrm{~A}-3 \mathrm{~A}$ in the appendix show plots of the Fourier spectra of the I/S ratios, and Figures 1B-3B show detrended sales and inventory movements of all 35 series. The horizontal axes of the plot of the spectra are labeled in multiples of $\pi$. Annual cycles are at $\pi / 6$, cycles of 6 months are at $\pi / 3$, and so on. The magnitude of the spike at each frequency gives an indication of the dominant cycles. In Figure 1A, the Fourier spectrum of the I/S ratio of the Stone, Clay and Glass Products sector has a high annual component (compared to 6month). Figure 1B shows for that industry a negative correlation between detrended inventory and sales. By comparison, the Instruments and Related sector shows a high 3-month (quarterly) component (compared to annual) in Figure 1A. The corresponding chart in Figure $1 \mathrm{~B}$ shows the high frequency composition of sales in this sector while inventory shows more of an annual cycle. Whereas the seasonally unadjusted variance ratio of Stone, Clay and Glass Products was 0.6864 , the variance ratio for Instruments and Related Products was 0.9359 .

For the three industries with positive covariance between sales and the change in inventory, Nonferrous and Other M etals (Figure 1A) and Paper and Allied Products (Figure 2A) show seasonal spikes in the I/S spectra, while no significant seasonality is depicted for Petroleum and Coal Products (Figure 2A). The positive co-movement between sales and inventory for all three is observable in Figures $1 \mathrm{~B}$ and $2 \mathrm{~B}$. For the Petroleum and Coal industry the positive co-movement between sales and inventory eliminates all seasonal components from the I/S ratio while the other two industries show higher swings in sales than inventory, leaving some seasonality in the ratio. 
SEPTEMBER/ O CTOBER 1999

The charts for this appendix follow on pages 34-39. 


\section{REVIEW}

SEPTEMBER/ OCTOBER 1999
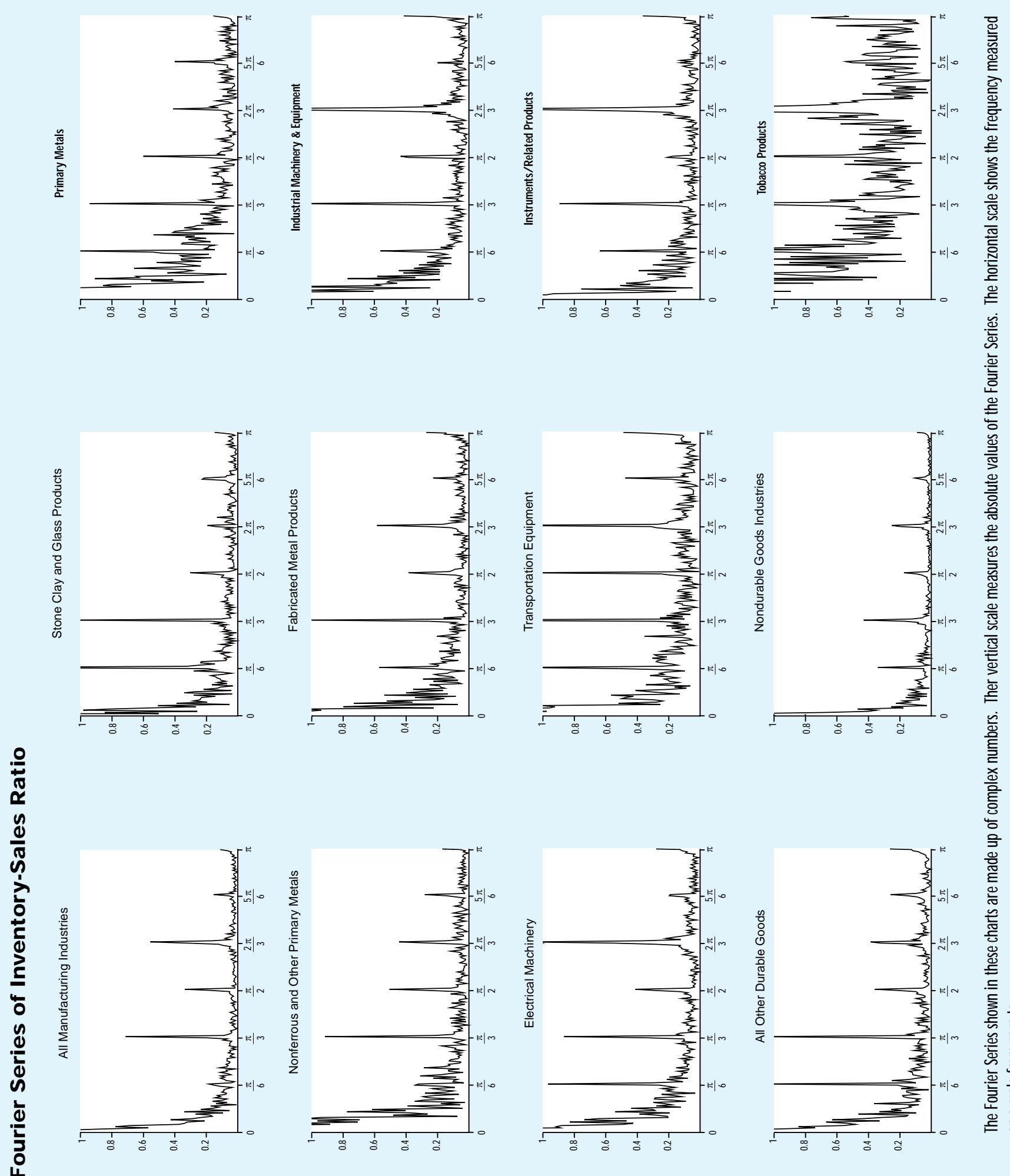

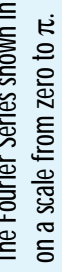




\section{REVIEW}

SEPTEMBER/ O CTOBER 1999
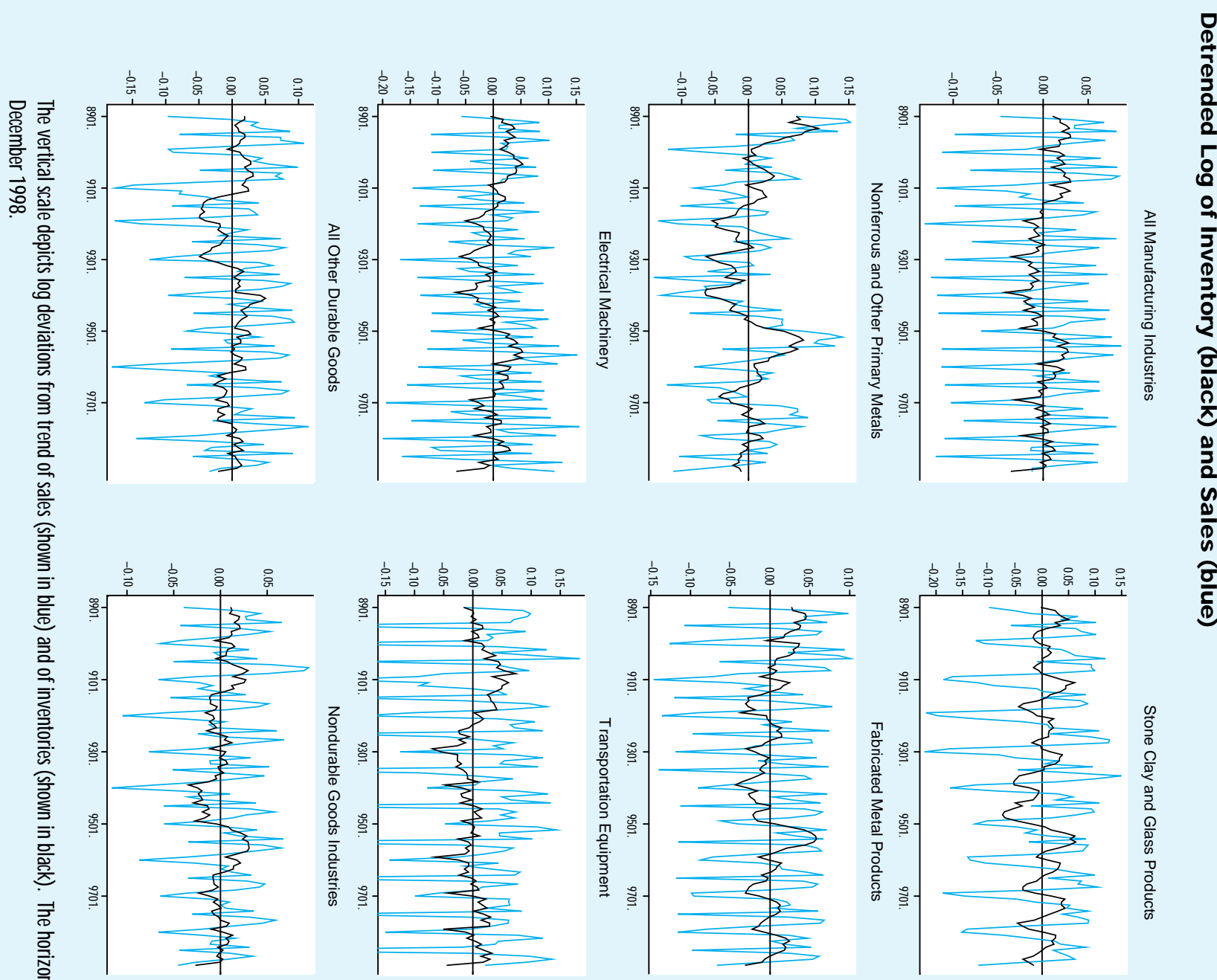

$\frac{\widehat{\sigma}}{\frac{\sigma}{D}}$
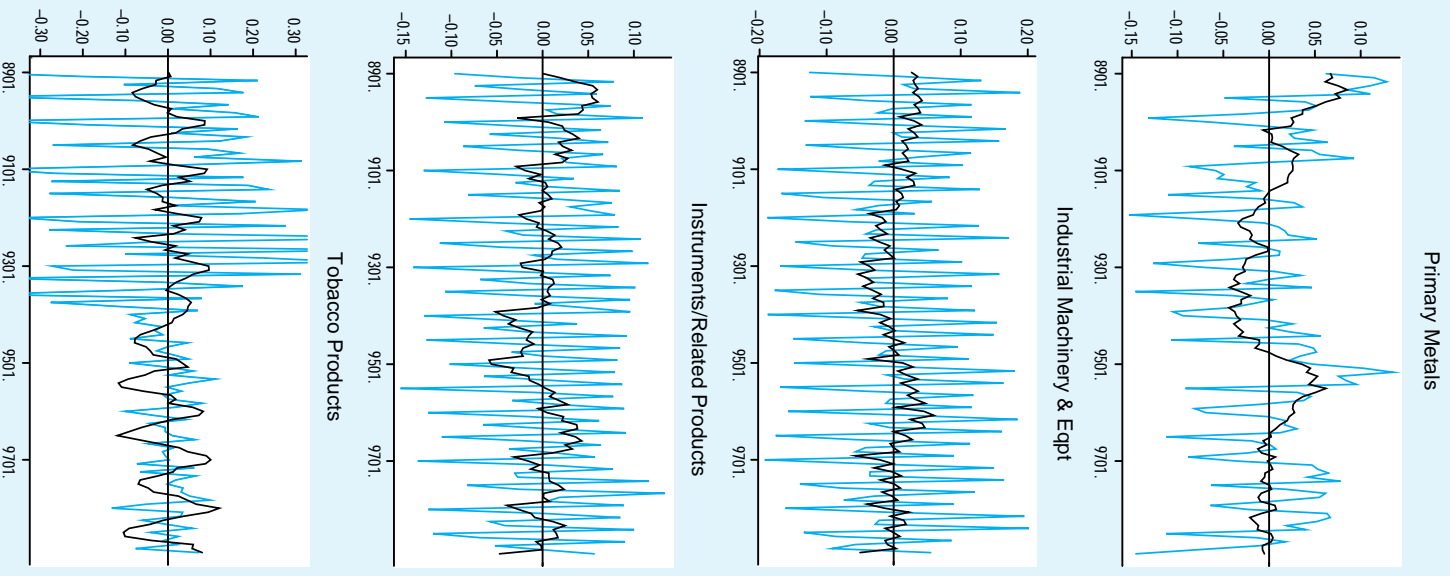

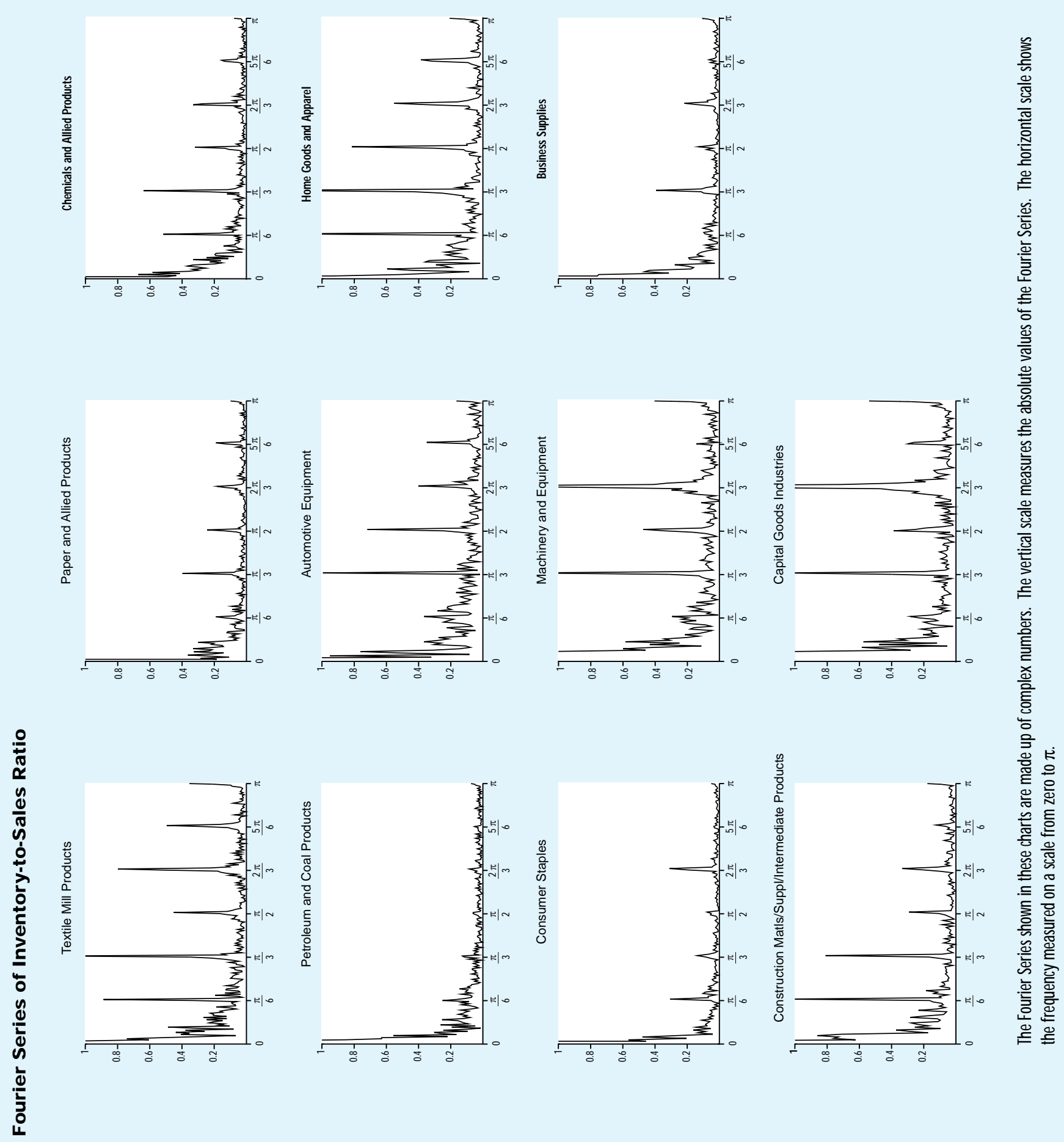

FEDERAL RESERVE BANK OF ST. LOUIS 


\section{REVIEW}

SEPTEMBER/ O CTOBER 1999
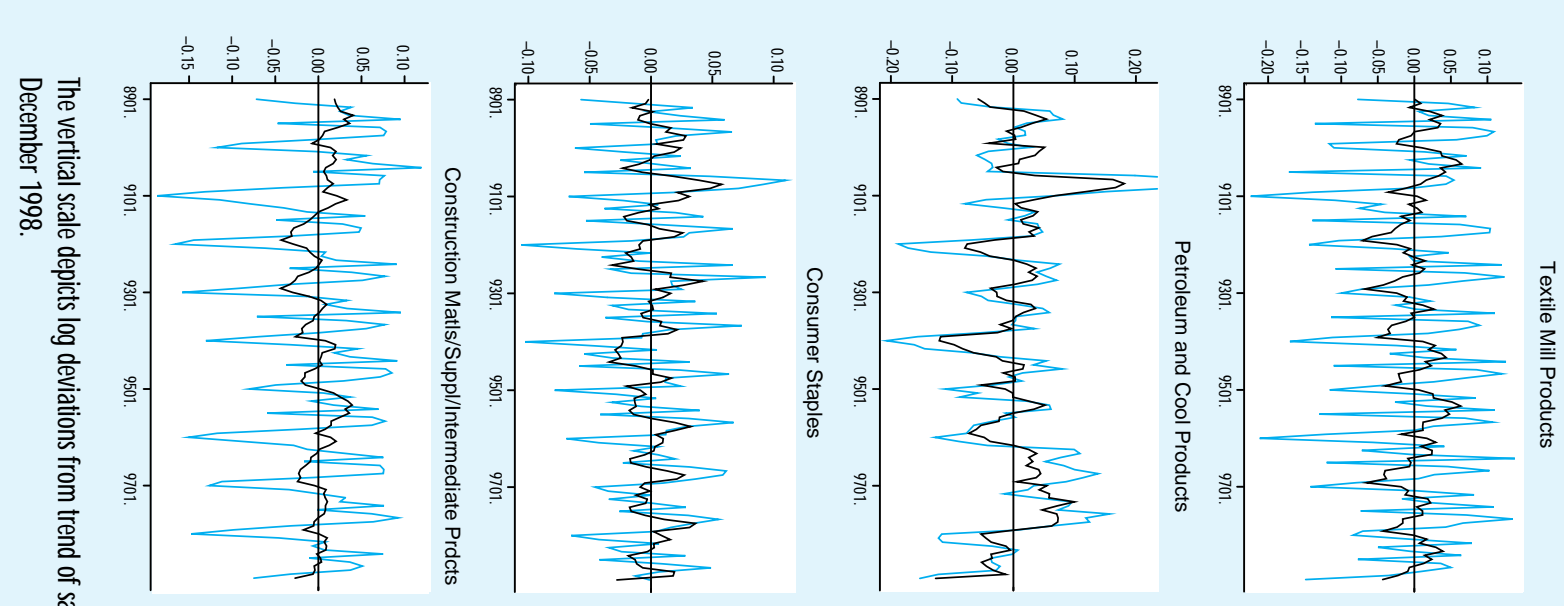

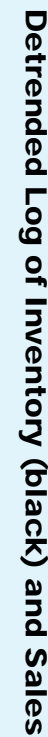
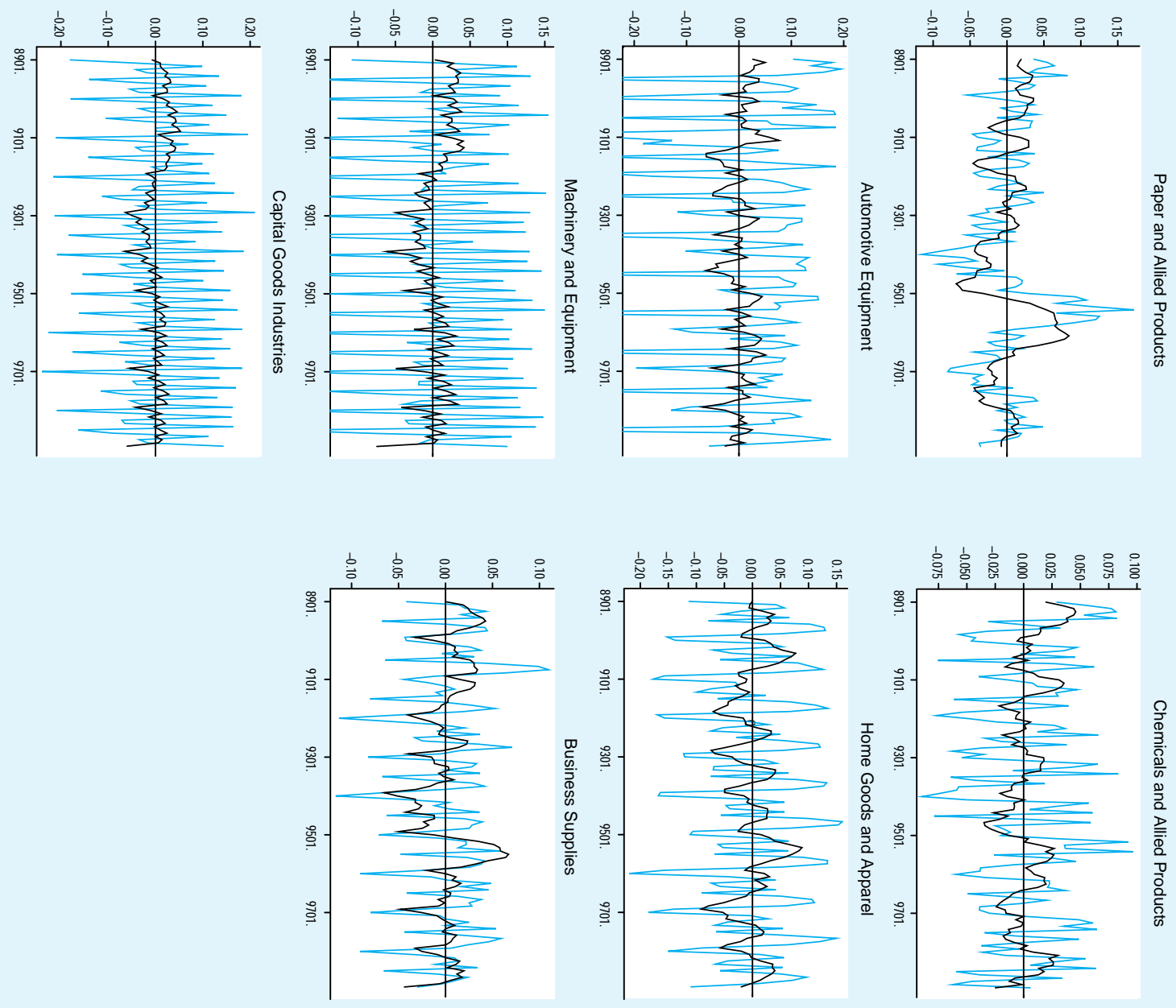

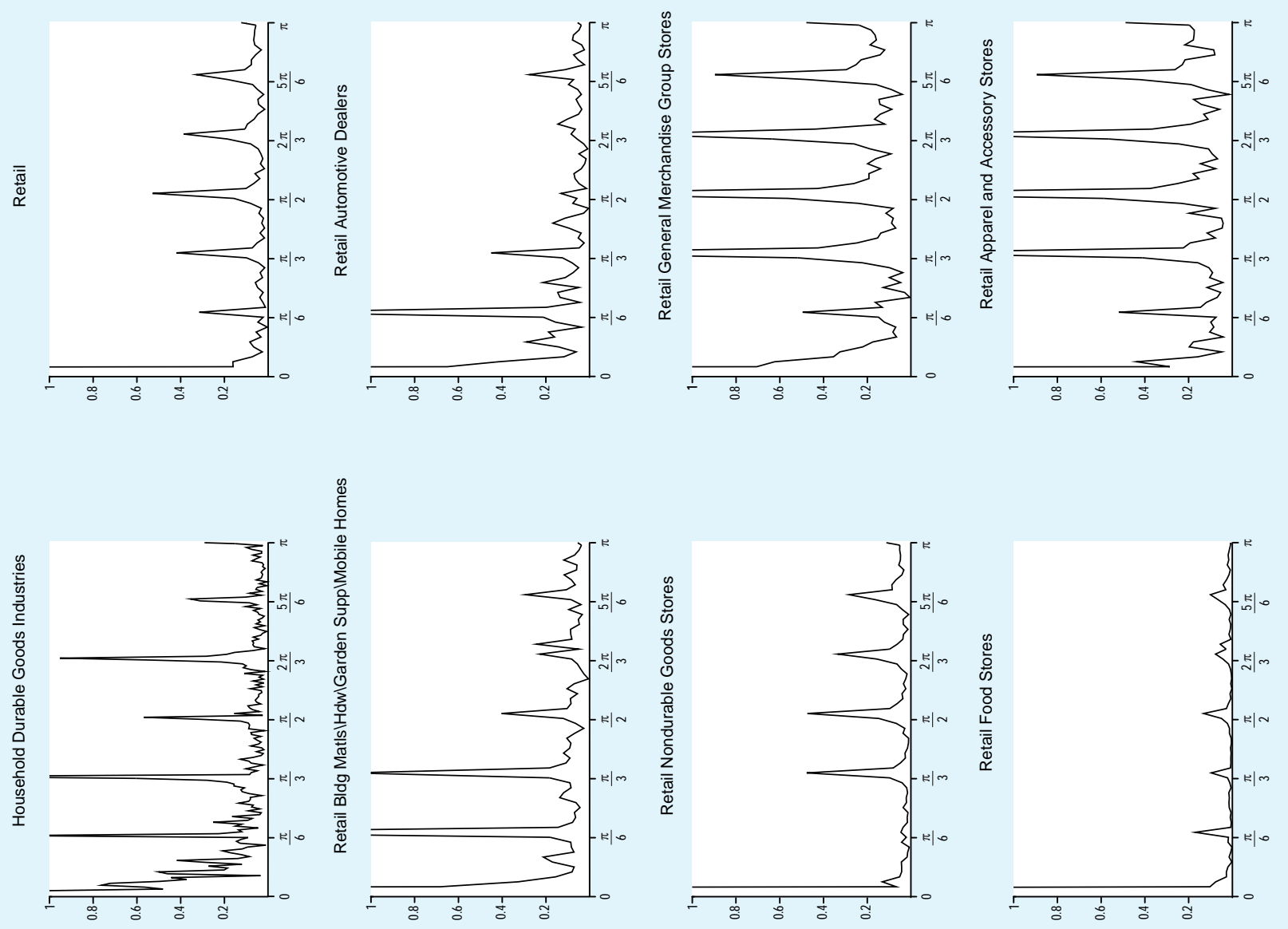

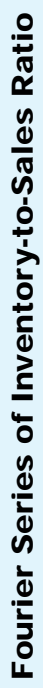
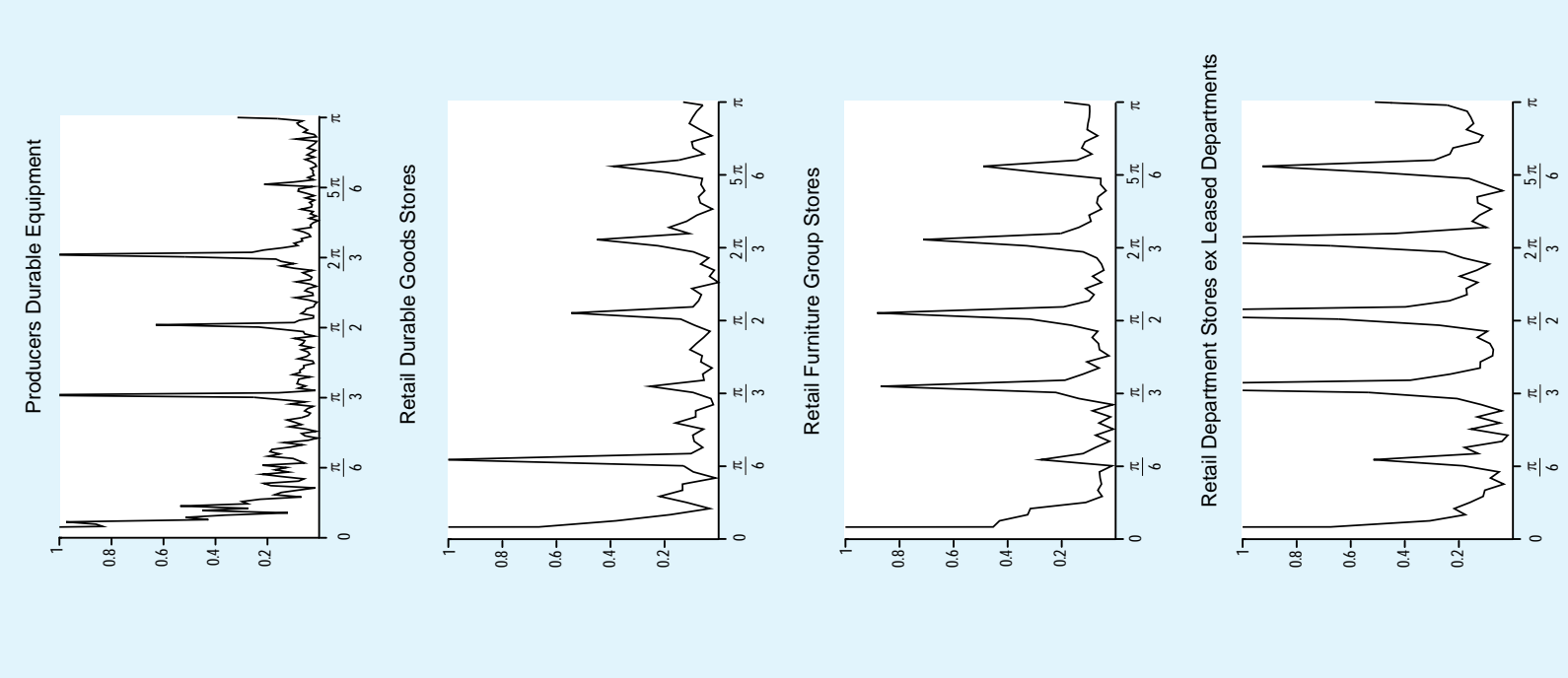

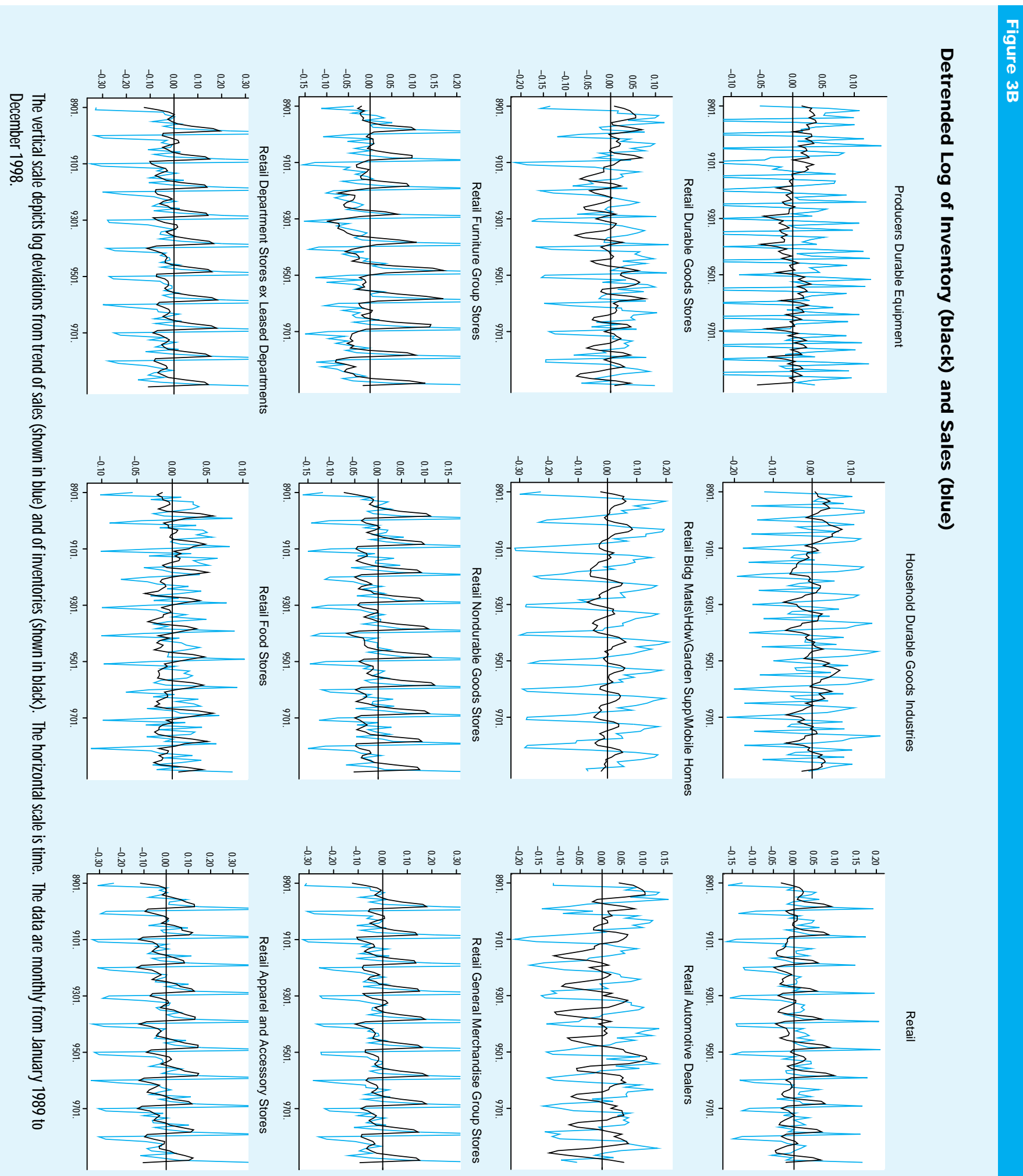


\section{REVIEW}

SEPTEMBER/ OCTOBER 1999

FEDERAL RESERVE BANK OF ST. LOUIS 